\title{
Introduction to the 2004 Howland Award Recipient, Frederick C. Battaglia
}

\author{
M. DOUGLAS JONES, JR. \\ Department of Pediatrics, The University of Colorado Health Sciences Center, The Children's Hospital, \\ Denver, CO 80218
}

Dr. Shapiro, members of the American Pediatric Society Council, and guests, it is an honor to introduce Dr. Frederick C. Battaglia as this year's Howland awardee. Fred was born in Weehawken, NJ, in 1932. He went on to receive his BA from Cornell, in $3 \mathrm{y}$, and his MD from Yale. At Yale, he had two experiences that would change his personal and professional life.

He was introduced to fetal physiology in the laboratory of Dr. Donald Barron, and he met Jane Donohue, a fellow medical student, who was to become his wife. Fred and Jane were married just after medical school graduation. Then they were off to Johns Hopkins for internships in pediatrics, another Battaglia innovation, a "couples match."

After completing a 1-y internship in Pediatrics at the Johns Hopkins Hospital, Fred went to England to spend a year studying biochemistry with Sir Philip Randle and then back to New Haven for a year in Dr. Barron's physiology laboratory. He returned to Johns Hopkins to finish his residency, traveling by train on alternate weekends to Yale to continue work in Barron's laboratory. Those were productive years. By the time he finished his residency, Fred had 16 publications, two in Nature.

Fred then spent $2 \mathrm{y}$ in Puerto Rico at the National Institutes of Health-funded Laboratory of Perinatal Physiology. He worked with obstetricians such as Sam Seeds, later to be chair at Cincinnati, and fellow pediatricians such as Dick Berhman, headed for a long career of leadership positions in pediatrics and academic medicine. He would continue as a true perinatologist, working with both obstetricians and pediatricians, throughout his career.

He returned from Puerto Rico to an appointment as assistant professor of pediatrics at the Johns Hopkins University School of Medicine in 1963. There he worked with the obstetricians Andre Hellegher's and Harry Prystowski. None was to be at Hopkins for long. Helleghers soon left to found the ethics program at Georgetown. Harry Prystowski went on to be chair of obstetrics and gynecology at Florida and then dean at Penn State in Hershey, and in 1965, despite admonitions from his chair, Dr. Robert Cooke, also a Howland medalist, that he was going to the "sticks" or

Received December 3, 2004; accepted December 9, 2004

Correspondence: M. Douglas Jones, Jr., M.D., Department of Pediatrics, The University of Colorado Health Sciences Center, The Children's Hospital, 1056 E. 19th Avenue B065, Denver, CO 80218; e-mail: jones.doug@tchden.org.

Presented at the 2004 Annual Meeting of the Pediatric Academic Societies, San Francisco, CA. May 1-4, 2004

DOI: 10.1203/01.PDR.0000179402.55662.4D worse, Fred moved from Johns Hopkins to the University of Colorado School of Medicine as an associate professor in both pediatrics, and obstetrics and gynecology.

Colorado was in fact far from being a frontier outpost. Thanks to the leadership of Drs. Harry Gordon, another Howland medalist, E. Stewart Taylor, chair of obstetrics and gynecology, and their pupil Lula Lubchenco, Colorado was by then famous for innovation in perinatal medicine. The chair of the department of pediatrics was Henry Kempe, yet another Howland medalist. Jane thought that Colorado might be only a stop on the way to somewhere else, but she and Fred and their children, Sue and Tom, were in Colorado for good.

By 1970, Fred had created the Division of Perinatal Medicine, joining with Drs. Giacomo Meschia in physiology and Ed Makowski in obstetrics and gynecology. This expressed Fred's conviction that to be successful, perinatal medicine had to be interdepartmental and comprehensive. Fred then went on to serve as chairman of the Department of Pediatrics at Colorado from 1974 to 1988 . He remains on the faculty as an emeritus professor of pediatrics and obstetrics and gynecology.

Fred has developed the twin themes of fetal physiology, from Donald Barron, and metabolism, from Sir Philip Randle, in over 350 publications. His investigations at Yale and Hopkins began with descriptions of basic characteristics of amniotic fluid, placental membranes, and fetal and maternal blood, continuing in the scientific tradition of Sir Joseph Barcroft, the pioneer in fetal physiology, and Barcroft's star pupil, Donald Barron. The intent was to develop an understanding of the exchange of gases, electrolytes, and metabolic substrates across the mammalian placenta.

Barron's pupil and later colleague at Yale, Giacomo Meschia, had refined Barcroft and Barron's fetal sheep preparation to the point that it could be used to study fetal and maternal blood flow and metabolism over a long period of intrauterine life. Fred was able to attract Giacomo, by then his brother-in-law, to Colorado. Their studies in collaboration with the obstetrician Ed Makowski and a series of pediatric and obstetric fellows soon extended to individual fetal organs and the placenta. Over the years, Fred and Giacomo's increasingly sophisticated explorations have demonstrated complex metabolic interrelationships between fetus, placenta, and mother. They showed that placenta is far more than an exchanger of gases and nutrients; it is also a fetal metabolic organ of critical importance.

Fred and Giacomo's insights from years of work in the fetal sheep have been used as the basis for a series of clinical studies over the past $20 \mathrm{y}$ in normal and intrauterine growth-restricted 


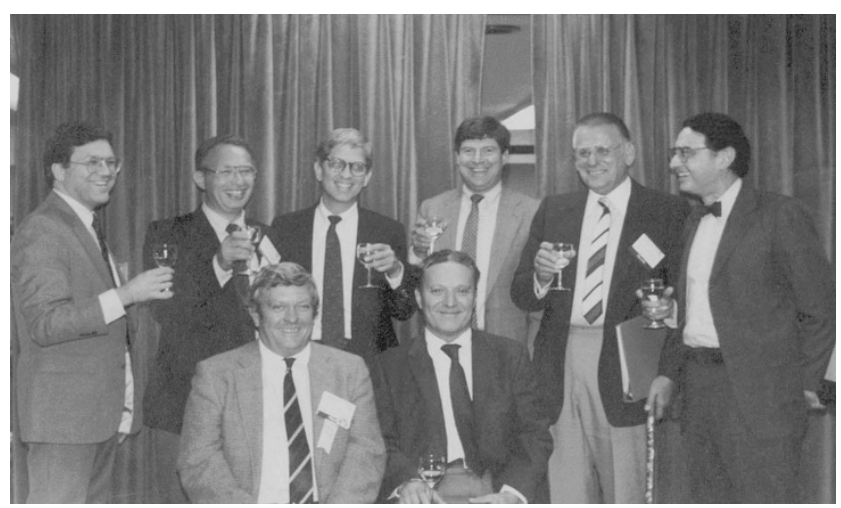

Figure 1. Fred Battaglia (back row, far right) at the time of the 1984 Apgar Award presentation to Giacomo Meschia (front row, right). Also shown are Joe Butterfield (front row, left) and (back row, beginning on the left) Gene Adcock, Harry Bard, Doug Jones, Mike Simmons, and Ed Makowski.

human pregnancies in collaboration with Professor Giorgio Pardi's group in Milan. Fred has been a master in the use of biologic diversity to gain insight into nature's solutions to fundamental problems. Although human and ovine pregnancies seemed initially to be far more different than similar, the opposite is true. The intellectual infrastructure provided by experiments in sheep was thus available to inform studies in humans. There is no better example of, to use the currently fashionable term, "translational research."

Dr. Battaglia's keen insights were by no means restricted to basic research. He was among the first to recognize the fundamental relationship of birth weight and gestational age to neonatal morbidity and mortality in a landmark 1967 paper co-authored with Lula Lubchenco. That observation is now taken for granted, the ultimate tribute. He was among the first, in a paper in the New England Journal of Medicine with Mike Simmons as first author, to take intraventricular hemorrhage in premature infants beyond pathologic description into considerations of pathophysiology.

Fred's contributions have been recognized with a number of awards. He has been a member of the Institute of Medicine of the National Academy of Sciences for almost $20 \mathrm{y}$. The American Academy of Pediatrics has recognized his contributions with the E. Mead Johnson Award for Pediatric Research, the Faculty Teaching Award, the Borden Nutrition Award, and the Virginia Apgar Award in Perinatal Medicine. He joins fellow Coloradans Lula Lubchenco, Giacomo Meschia, and Joe Butterfield in the select group of Apgar awardees (Fig. 1). Fred received the Agnes Higgens Award from the March of Dimes and is an honorary member of both the American Gynecologic and Obstetrical Society and the Society for Maternal-Fetal Medicine. He has honorary degrees from the University of Indiana and the University of Colorado.

Dr. Battaglia has been a leader as have few others. He served as president of the Society for Pediatric Research, the Western Society for Pediatric Research, the American Society of Pediatric Department Chairmen, now the Association of Medical School Pediatric Department Chairs, the American Pediatric Society and the World Association of Perinatal Medicine. He was a founding member, then secretary-treasurer, then president of the Perinatal Research Society, which was founded, like the Division of Perinatal Medicine at Colorado, on the principle of equal representation by neonatologists, obstetricians, and basic scientists. He has served on numerous editorial boards.

His accomplishments as an educator warrant separate comment. He was the 1991 recipient of the Medical Education Award of the American Academy of Pediatrics for developing and implementing the Pediatric Scientists Training Program (PSTP). The PSTP, now the PSDP, the Pediatric Scientist Development Program, was established in response to a shortage of pediatricians with expertise in basic research. It was designed to provide pediatric clinicians with $2-3$ y of basic science research training. Fred had the idea and, more important, the organizational skill and commitment to bring together a funding consortium of the National Institute of Child Health and Human Development, the National Foundation/March of Dimes, the American Academy of Pediatrics, the American Pediatric Society, St. Jude Children's Research Hospital, The Hospital for Sick Children Foundation, and others. The impact on academic pediatrics has been enormous. PSDP fellows have been heavily recruited since the inception of the program; of the 108 fellows who trained from 1987 through 2003, 100 currently hold academic, industry, or National Institutes of Health research appointments. It is the most successful physician-scientist training program in the country.

Fred was also the guiding force and then leader of the American Academy of Pediatrics Residency Research Award Committee. He was among the first to establish an "academic track" to mentor residents interested in a research project during their general pediatric residency. At the same time, he was among the first to see the benefit of a "primary care track" for some residents. The first such resident was Steve Berman, recently president of the American Academy of Pediatrics.

Dr. Bartaglia's innovative approach to bringing basic science to the practicing pediatrician resulted in the Mead Johnson Clinical Scholars program, now in its 23rd year. Each medical school department chair is asked to nominate a pediatrician from the community. The program brings a group of 25 nominees together with outstanding basic scientists for a 3-d seminar. Fred long ago convinced those who doubted that practicing pediatricians would be interested in basic science topics far removed from their daily professional lives. The best evidence is from the attendees themselves. Every year, up to 10 alumni are allowed to attend another meeting at their own expense. The quota is fully subscribed.

Dr. Battaglia's trainees have gone on to success in academic pediatrics and obstetrics. Among them are three deans of schools of medicine, nine chairs of departments of pediatrics, two chairs of departments of obstetrics and gynecology, over two dozen full professors, and a number of others who have served in various capacities in academic institutions.

I commend Dr. Fred Battaglia as this year's Howland awardee. Few pediatricians, indeed few in medicine, have matched the breadth and depth of his contributions. 